\title{
Model regenerasi dan kaderisasi kepemimpinan pondok pesantren di Kabupaten Bogor
}

\author{
Saiful Falah \\ Institut Ummul Quro Al-Islami Bogor \\ saiful.falah@iuqibogor.ac.id
}

\begin{abstract}
Abstrak
Pesantren di Indonesia berdiri sebagai penjaga tradisi dan budaya Islam. Sejak zaman prakolonial sampai sekarang pesantren memainkan peran penting dalam membangun masyarakat. Kiai sebagai tokoh utama di pesantren menentukan eksistensi pesantren. Oleh karena itu pesantren harus dilestarikan. Makalah ini membahas upaya pelestarian pesantren melalui regenerasi. Secara khusus pada model regenerasi yang digunakan oleh pesantren di Bogor. Pendekatan yang digunakan pada penelitian ini adalah kualitatif dengan metode survei. Data dianalisis dari bahan yang dikumpulkan berdasarkan penelitian lapangan dan kepustakaan. Penelitian ini menemukan bahwa kiai pesantren di Bogor banyak melakukan regenerasi model keturunan. Kepemimpinan di pesantren diwarisi dari kiai sebagai pendiri kepada anaknya atau menantu. Untuk melestarikan kekuasaan kiai menyiapkan pengganti sejak dini. Ini disebut sebagai kaderisasi. Upaya ini meliputi penentuan nilai dasar, pelaksanaan program dan evaluasi. Nilai dasar yang diharapkan dari kader mencakup akhlak, ibadah, keilmuan, manajerial dan dedikasi. Program kaderisasi mencakup pendidikan dan penugasan. Evaluasi meliputi pendekatan pribadi dan manajerial.
\end{abstract}

Kata kunci: kaderisasi, kepemimpinan, pesantren, regenerasi

\section{Pendahuluan}

Suatu hal yang tidak terlepas dalam wacana pendidikan di Indonesia adalah Pondok Pesantren. Sebuah lembaga pendidikan yang khas Indonesia. Keberadaannya mengilhami model dan sistem-sistem yang ditemukan saat ini. Lembaga ini bahkan tidak lapuk dimakan zaman dengan segala perubahannya. Karenanya banyak pakar, baik lokal maupun internasional melirik Pondok Pesantren sebagai bahan kajian. Tidak jarang beberapa tesis dan disertasi menulis tentang lembaga pendidikan Islam tertua ini. (Bruinessen \& Martin, 1999)

Diserahkan: 4-April-2019 Disetujui: 14 April 2016. Dipublikasikan: 26 April 2019

Kutipan: Falah, S. (2019). Model regenerasi dan kaderisasi kepemimpinan pondok pesantren di Kabupaten Bogor. Ta'dibuna: Jurnal Pendidikan Islam, 8(1), 1-16. doi:http://dx.doi.org/10.32832/tadibuna.v8i1.1782 
Zamakhsyari Dhofir merupakan putra pribumi yang menjadi pionir dalam penelitian tentang pesantren. Pada tahun 1980, pria yang sekarang menjabat sebagai Rektor Universitas Sains Al-Qur'an di Wonosobo Jawa Tengah menulis disertasi doktor antropologi sosial di The Australian National University tentang tradisi pesantren. Naskah tersebut kemudian diterbitkan oleh The Arizona State University, Arizona, USA (Dhofier, 2011).

Yanwar Pribadi dalam disertasi di Leiden University membuktikan peran besar pesantren dalam mewarnai masyarakat. Penelitian yang dilakukan di pulau Madura tersebut menunjukkan bahwa peningkatan jumlah pesantren berdampak pada terjaganya nilai-nilai keislaman di tengah masyarakat. Tahun 1995 di Bangkalan tercatat ada 145 pesantren, tahun 2000 meningkat jadi 169, dan tahun 2006 menjadi 305 pesantren (Pribadi, 2013).

Pesantren laksana harta yang tidak ternilai harganya. Keberadaan pesantren di Indonesia sangat penting. Marzuki Wahid dalam The Metamorphosis of Pesantren menulis bahwa pesantren dengan segala tradisinya mampu bertahan di dunia yang menganggap 'tradisi' sebagai masalah atau rintangan. Ini menunjukkan bahwa pesantren adalah penjaga tradisi bangsa (Wahid, 2008).

Pemikiran yang berkembang di suatu institusi tentu tak pernah terlepas dari pemikiran pemimpin pesantren tersebut. Dalam hal ini pemikiran suatu pesantren tidak akan pernah lepas dari pemikiran Kiai yang memimpin pesantren tersebut. Di pesantren kiai merupakan figur sentral. Sosok kiai tidak ubahnya raja di sebuah kerajaan. Segala kebijakan pesantren adalah domain kiai.

Keberadaan pesantren sebagai benteng bangsa tentu harus dijaga. Satu cara terbaik menjaga eksistensi pesantren adalah dengan kaderisasi. Pesantren identik dengan sosok Kiai, maka upaya pelestarian pesantren harus dimulai dari mencetak calon kiai. Dalam hal ini regenerasi di pesantren harus diperhatikan.

Pesantren Darussalam Gontor memberi contoh tentang bagaimana regenerasi dilakukan. Estafet kepemimpinan dari generasi pertama Trimurti, KH. Ahmad Sahal, KH. Zainuddin Fannani dan KH. Imam Zarkasyi ke generasi kedua berjalan mulus. Tahun 1967 K.H. Zainuddin Fanani, salah seorang dari Trimurti Pendiri Pondok wafat. Kemudian disusul oleh K.H. Ahmad Sahal yang wafat tahun 1977. Dan pada April 1985, Trimurti terakhir KH. Imam Zarkasyi meninggal dunia. Sepeninggal beliau tongkat kepemimpinan Gontor diserahkan kepada generasi kedua. Dalam siding Badan Wakaf ditetapkan tiga pimpinan baru: Kh. Shoiman Lukmanul Hakim, KH. Abdullah Syukri Zarkasyi, MA., dan KH. Hasan Abdullah Sahal. Pada tahun 1999, KH. Shoiman wafat. Posisi beliau digantikan oleh KH. Imam Badri (Zarkasyi, 2005).

Di bawah kepemimpinan Trimurti jilid dua Gontor semakin berkembang. Di antara bukti perkembangan tersebut adalah pendirian lembaga kemasyarakatan bernama Pusat 
Latihan Manajemen dan Pengembangan Masyarakat (PLMPM) tahun 1988 di Ngawi, pembukaan pondok-pondok cabang Gontor, pembukaan Kampus Terpadu Institut Studi Islam Darussalam (ISID) di Ponorogo, pengembangan bidang ekonomi dengan mendirikan 23 unit usaha baru, persamaan ijazah dari Departemen Agama RI tahun 1998 dan penyetaraan dari Departemen Pendidikan Nasional tahun 2000 (Zarkasyi, 2005).

Di kabupaten Bogor terdapat ratusan pondok pesantren. Dari buku Data Pondok Pesantren Di Jawa Barat tahun 2013-2014 yang dikeluarkan oleh Kantor Wilayah Kementerian Agama Provinsi Jawa Barat tercatat ada 542 pondok pesantren. Data menyebutkan ratusan pondok pesantren tersebut terbagi ke dalam dua kelompok, pesantren salafiyah (tradisional) dan khalafiyah (modern). Jumlah itu menjadikan Bogor termasuk ke dalam lima besar kabupaten dan kota di Jawa Barat dengan jumlah pesantren terbanyak (Kanwil Kementerian Agama Prov. Jawa Barat, 2014).

Satu hal yang juga menarik dari data tersebut di atas, pondok pesantren yang jumlahnya lebih dari 542 di Kabupaten Bogor mayoritas santrinya tidak lebih dari 200 orang. Ini menandakan bahwa Pondok Pesantren yang tersebar di Kabupaten Bogor bukan pesantren besar. Bogor sebagai Kabupaten terpadat penduduknya di Indonesia tidak banyak memiliki pesantren besar.

Penelitian berjudul "Model Regenerasi dan Kaderisasi Kepemimpinan Pondok Pesantren di Kabupaten Bogor" dipilih karena sangat tepat untuk mengetahui proses pelestarian pesantren melalui program regenerasi dan kaderisasi. Model regenerasi dan kaderisasi tentu akan menentukan masa depan pesantren.

\section{Kajian Teoritis}

\section{A. Model regenerasi di pondok pesantren}

Sebagai lembaga pendidikan Islam yang asli Indonesia, pesantren memiliki aturan tersendiri dalam regenerasi. Kepemimpinan pesantren tidak seperti kepemimpinan sekolah bukan jabatan yang diperebutkan oleh banyak orang. Kepemimpinan pesantren berada di tangan kiai. Dan regenerasinya pun tergantung kiai. Hal ini terjadi karena kiai di pesantren adalah pendiri sekaligus pemilik.

Kedudukan kiai di pesantren sangat urgen. Kiai adalah matahari yang menjadi penerang. Kiai adalah awan yang menaungi. Kiai adalah air yang menghidupi. Kiai adalah bintang yang menentukan arah jalan. Maka tidak salah apabila Zamakhsyari Dhofier menyatakan bahwa pertumbuhan pesantren bergantung pada kemampuan pribadi kiainya (Dhofier, 2011).

Estafet pergantian kepemimpinan pesantren yang dimiliki oleh pribadi kiai terjadi di dalam keluarga terdekat; pendiri-anak-menantu-cucu-santri senior (Mastuhu, 1994). Zamakhsyari Dhofier menyebut ini sebagai genealogi sosial pemimpin pesantren. Regenerasi kepemimpinan terjadi di dalam keluarga terdekat kiai. Anak laki-laki pertama 
menjadi putra mahkota. Dia diberi privillage sebagai penerus utama. Apabila kiai tidak memiliki putra, maka pilihan akan jatuh kepada menantunya. Seterusnya estafet kepemimpinan diteruskan oleh cucu kiai pendiri. Ada saatnya santri senior diangkat menjadi pimpinan. Hal ini terjadi ketika generasi penerus kiai tidak memiliki kualitas yang mumpuni untuk memimpin pesantren.

Contoh regenerasi kepemimpinan pesantren model genealogi sosial terjadi di Pesantren Tebu Ireng Jombang. Pesantren tersebut didirikan oleh KH. Hasyim Asy'ari tahun 1899 M (Al-Madyuni, 2013). Setelah wafat KH. Hasyim Asy'ari digantikan oleh putranya KH. A. Wahid Hasyim (1947-1950). Sehubungan KH. A. Wahid Hasyim memiliki kesibukan di Jakarta, kepemimpinan pesantren diserahkan kepada saudaranya KH. A. Karim Hasyim (1950-1951). Beliau wafat setelah memegang kepemimpinan pesantren selama satu tahun, kemudian diganti oleh iparnya, KH. A. Baidhawi (1951-1952). Setelahnya, pimpinan pesantren kembali ke tangan putra pendiri, KH. A, Khaliq Hasyim (1952-1965), diteruskan oleh H. M. Yusuf Hasyim (Mastuhu, 1994). KH. M. Yusuf Hasyim memimpin Pesantren Tebu Ireng selama 41 tahun, dari 1965 sampai 2006. Dari 2006 sampai sekarang kepemimpinan Tebu Ireng dipegang oleh KH. Salahuddin Wahid, cucu pendiri pesantren KH. Hasyim Asy'ari sekaligus putra pimpinan kedua KH. A. Wahid Hasyim (Zaini \& K.H., 2011).

Pondok Modern Darussalam Gontor memiliki corak regenerasi kepemimpinan yang berbeda dengan Tebu Ireng. Pesantren Modern Gontor didirikan oleh tiga bersaudara KH. Ahmad Sahal, KH. Zainuddin Fanani, dan KH. Imam Zarkasyi. Tiga orang bersaudara ini biasa disebut Trimurti. Tahun 1967 K.H. Zainuddin Fanani wafat, disusul oleh K.H. Ahmad Sahal yang wafat tahun 1977. Delapan tahun berikutnya, 1985, K.H. Imam Zarkasyi pun menyusul kedua kakaknya. Sepeninggal Trimurti tongkat estafet kepemimpinan Pondok Modern Darussalam Gontor diserahkan kepada generasi kedua. Badan Wakaf Pondok Modern Darussalam Gontor menetapkan tiga Pimpinan Pondok untuk memimpin Gontor setelah Trimurti. Ketiga Pimpinan itu adalah K.H. Shoiman Luqmanul Hakim, K.H. Abdullah Syukri Zarkasyi, MA., dan K.H. Hasan Abdullah Sahal (Masqon, 2015).

Regenerasi di Pondok Modern Gontor tidak hanya meliputi keturunan pendiri. KH. Shoiman Lukmanul Hakim bukan putra pendiri pesantren. Beliau merupakan santri senior yang sudah masuk Gontor sejak tahun 1936. Pada tahun 1999, KH. Shoiman Lukmanul Hakim wafat. Posisi beliau digantikan oleh KH. Imam Badri. Saat ini Gontor dipimpin oleh KH. Abdullah Syukri Zarkasyi, KH. Hasan Abdullah Sahal, dan KH. Syamsul Hadi Abdan(Zarkasyi, 2005).

\section{B. Model kaderisasi di pondok pesantren}

Model kaderisasi yang berhasil menjadi wasilah kelestarian pesantren telah dilakukan oleh KH. Hasyim Asy'ari pendiri Pesantren Tebu Ireng Jombang. Sejak dini 
beliau mengader putranya A. Wahid Hasyim untuk menjadi pemimpin masa depan. Berikut adalah model kaderisasi yang dilakukan KH. Hasyim Asy'ari.

\section{Pendidikan}

KH. Hasyim Asy'ari sangat memperhatikan pendidikan putra-putrinya, terutama pendidikan agama. Bekal utama tersebut adalah dasar pembentukan kepribadian yang baik. Sejak kecil A. Wahid Hasyim belajar di bawah bimbingan ayahanda. Membaca AlQur'an merupakan materi inti yang diajarkan sang ayah selepas Dzuhur dan Maghrib. Selain Al-Qur'an, Wahid pun diajarkan Bahasa Arab dan kitab kuning. Di antara kitab yang dipelajari semenjak umur tujuh tahun adalah Fath al-Qarib, Minhaj al-Qawim dan Mutammimah (Zaini \& K.H., 2011).

Sebagai calon kiai, A. Wahid Hasyim dikirim untuk belajar ke pesantren lain. Meskipun Tebu Ireng adalah pesantren besar dan pimpinannya ketua para kiai Nahdhatul Ulama, seorang kader tidak cukup belajar di pesantren orang tuanya. Pada usia 13 tahun, A. Wahid Hasyim mulai melakukan pengembaraan ilmu. Pesantren pertama yang menjadi pelabuhan menuntut ilmu adalah Pondok Siwalan Sidoarjo. Kemudian diteruskan ke Pesantren Lirboyo, Kediri. Pesantren Lirboyo sendiri dipimpin oleh KH. Abdul Karim, murid kesayangan KH. Hasyim Asy’ari (Al-Madyuni, 2013).

Proses menimba ilmu di pesantren lain membuat A. Wahid Hasyim tambah cinta ilmu. Kecenderungan tersebut membuat senang ayahanda. Saat dirasa putranya cukup dewasa untuk belajar ke luar negeri, KH. Hasyim mengizinkan Wahid berkelana ke Mekah. Di daerah yang menjadi kiblat ilmu pengetahuan agama tersebut, Wahid muda menimba ilmu dari para syaikh di Masjidil Haram. Tahun 1932 Wahid muda menghabiskan masanya di Mekah belajar Tafsir, Hadith, Fiqh dan Tasawuf kepada Syaikh Umar Hamdan dan Syaikh Abdul Wahhab al-Khuqir (Zaini \& K.H., 2011).

\section{Penugasan}

Bermodal ilmu yang didapat baik dari Tebu Ireng, pesantren-pesantren yang didatangi, serta Mekah, A. Wahid Hasyim siap menerima tugas. KH. Hasyim Asy'ari menunjuk anak laki-lakinya tersebut menjadi asisten pribadi. Wahid Hasyim ditugasi menjawab surat-surat yang berkaitan dengan fiqh yang ditujukan kepada ayahnya dan mendatangi pengajian atau ceramah.

Tebu Ireng dikenal sebagai pesantren rujukan. Pada waktu tertentu KH. Hasyim menyelenggarakan pengajian kitab Bukhari. Pengajian ini terbuka bagi umum. Banyak pimpinan pesantren di Jawa yang menyempatkan diri menghadiri pengajian tersebut. Mbah Hasyim terkenal sebagai ulama Hadits. Ketika KH. Hasyim Asy'ari sakit, A. Wahid Hasyim ditugasi untuk menggantikan beliau mengajar. Maka Wahid muda pun membaca kitab Bukhari di hadapan para kiai yang tentunya lebih tua darinya. 


\section{Keteladanan}

KH. Hasyim Asy'ari diakui sebagai ulama Indonesia yang paling berpengaruh di pertengahan abad 20. Para kiai menganugerahkan gelar Hadratus Syekh yang artinya Tuan Guru Besar kepada beliau. Gelar tersebut bentuk apresiasi atas keilmuan yang dimiliki oleh KH. Hasyim Asy'ari. Beliau adalah ahli hadits yang mendapat ijazah mengajarkah kitab Bukhari oleh Ulama ternama Syekh Mahfudh at-Tarmisi (Dhofier, 2011).

Hadratus Syekh tipe ulama yang cinta ilmu. Sepanjang hayatnya dicurahkan untuk belajar dan mengajar ilmu. Semasa muda beliau mengkaji ilmu dari banyak pesantren di Indonesia. Bahkan beliau pergi ke Mekah untuk belajar ilmu agama dari sumber utama. Semangat beliau diteruskan oleh putranya A. Wahid Hasyim. Seolah mengikuti jejak ayahanda, Wahid Hasyim belajar dari pesantren ke pesantren. Seterusnya pemuda asal Jombang tersebut menggali ilmu di tanah suci (Al-Madyuni, 2013).

KH. Hasyim Asy'ari memberi teladan kepada putranya bahwa seorang kiai tidak hanya mengajar mengaji di pesantren, kiai harus aktif membangun masyarakat melalui organisasi. Kiai adalah motor penggerak peradaban yang selalu peka terhadap harapan dan tantangan. Saat kaum tradisional mendapat ancaman dari gerakan yang dilakukan oleh kaum modernis, KH. Hasyim Asy'ari maju ke depan untuk mempertahankan tradisi. Bentuk perjuangan beliau diwujudkan melalui jam'iah Nahdhatul Ulama yang didirikan pada tanggal 16 Rajab 1344 H/31 Januari 1926 M. Hadratus Syekh didaulat menjadi rais akbar.

Teladan Hadratus Syekh dalam keterlibatan di organisasi masyarakat diikuti oleh putranya. A. Wahid Hasyim tercatat menjadi anggota NU pada tahun 1938. Setelah itu kariernya meningkat, menjadi ketua NU cabang Jombang dan dua tahun kemudian dipromosikan menjadi pengurus pusat. Pada tahun 1945, Wahid Hasyim beserta para ulama Indonesia mengadakan Muktamar Umat Islam Indonesia di Yogyakarta. Hasil kongres ini adalah pembentukan Majelis Syuro Muslimin Indonesia disingkat Masyumi, satu-satunya partai politik umat Islam Indonesia. A. Wahid Hasyim diangkat menjadi ketua (Zaini \& K.H., 2011).

\section{Metodologi Penelitian}

Penelitian ini menggunakan pendekatan kualitatif. Metode kualitatif disebut sebagai metode postpositivism karena dipandang sebagai kritik terhadap positivism (Burhan, 2010). Sehingga keberadaan peneliti menjadi bagian integral dalam penelitian. Hal ini dikarenakan dalam penelitian kualitatif instrumennya adalah orang atau human instrument, yaitu peneliti sendiri (Sugiyono, 2013). Metode yang digunakan dalam penelitian ini adalah metode survei. Adapun teknik pengambilan sampel yang digunakan adalah purposive sampling. 
Peneliti memilih sampel berdasarkan kebutuhan penelitian dengan pertimbangan bahwa sampel dapat memberi informasi mendasar terkait dengan objek penelitian. Sesuai dengan judul penelitian, maka sampel yang diambil berasal dari data pesantren di kabupaten Bogor. Menurut data Kementerian Agama Republik Indonesia Kantor Wilayah Jawa Barat, jumlah pesantren di kabupaten Bogor sebanyak 542 pondok pesantren. Ada dua macam pesantren; salaf dan khalaf.

Setelah peneliti melakukan verifikasi data di lapangan, terdapat 30 pesantren yang memiliki jumlah santri 200 atau lebih. Adapun pesantren lain memiliki santri kurang dari 200. Pesantren yang memiliki santri lebih dari 200 tersebut dijadikan sampel penelitian. Dengan jumlah santri yang berkisar antara 200 s/d 3000 santri, pondok pesantren tersebut harus dipertahankan bahkan ditingkatkan. Salah satu usaha untuk mempertahankan eksistensi pesantren melalui program kaderisasi dan regenerasi.

Adapun nama-nama pesantren yang dijadikan sampel sebagai berikut

Tabel 1. Nama pesantren di bogor dengan santri di atas 200

\begin{tabular}{cllcc}
\hline NO & \multicolumn{1}{c}{ NAMA PESANTREN } & \multicolumn{1}{c}{ ALAMAT } & TAHUN BERDIRI & JUMLAH SANTRI \\
\hline 1 & Al-Mukhlisin & Ciseeng & 1984 & 1730 \\
2 & Darul Muttaqien & Parung & 1988 & 540 \\
3 & Darunna'im YAPIA & Parung & 1983 & 1450 \\
4 & Al-Ghozali & Gunung Sindur & 1982 & 353 \\
5 & Daruttaqwa & Cibinong & 1976 & 525 \\
6 & Nurul Furqon & Cibinong & 1992 & 743 \\
7 & Darunnajah & Cigudeg & 1988 & 930 \\
8 & Darut Tafsir & Ciampea & 1974 & 200 \\
9 & Darul Fallah & Ciampea & 1960 & 217 \\
10 & Hidayat El-Ikhwan Salafiyah & Tenjo & 1958 & 359 \\
11 & Hidayat El-Ikhwan Kholafiyah & Tenjo & 1958 & 310 \\
12 & Al-Itqon & Cibungbulang & 1998 & 300 \\
13 & Sahid & Cibungbulang & 2000 & 840 \\
14 & Al-Kahfi & Cigombong & 2002 & 846 \\
15 & Darul Ulum Lido & Cigombong & 1996 & 2000 \\
16 & Miftahussa'adah Salafiyah & Cigombong & 1955 & 370 \\
17 & Mualimin Muhammadiyah & Leuwiliang & 1970 & 249 \\
18 & Mafazah & Leuwiliang & 2005 & 284 \\
19 & Nurul Iman Al-Hasanah & Leuwiliang & 1992 & 600 \\
20 & Nurul Hidayah Salafiyah & Luewisadeng & 1963 & 500 \\
21 & Darul Ulum 2 & Sukaraja & 1983 & 349 \\
22 & Ar Rahmaniyah & Tajurhalang & 2001 & 490 \\
23 & MDII Ibnu Aqil & Ciomas & 1987 & 371 \\
24 & Al-Ikhlas Salafiyah & Mega Mendung & 1950 & 383 \\
25 & Hidayatut Thalibin & Bojong Gede & 1999 & 374 \\
26 & Al-Fiqoriyah & Bojong Gede & 1990 & 473 \\
27 & Darul Mughni & Klapa Nunggal & 1998 & 2530 \\
28 & Tarbiyatul Huda & Caringin & 1982 & 506 \\
29 & Raudhotut Tauhid & Rumpin & 2008 & 708 \\
30 & Nurul Hidayah Al-Qurdiyah & Jasinga & 1973 & 200 \\
& Salafiyah & & & \\
\hline & & & &
\end{tabular}




\section{Hasil dan Pembahasan}

\section{A. Model regenerasi kepemimpinan pondok pesantren di kabupaten bogor}

Dari sampel yang diteliti sebanyak 30 pesantren di kabupaten Bogor, ada 23 pesantren yang sudah melakukan regenerasi. Model yang dilaksanakan dalam regenerasi pimpinan pesantren sampel ada tiga; keturunan, organisasi, dan caretaker. Mayoritas kiai di kabupaten Bogor masih kuat memegang tradisi melakukan regenerasi model keturunan. Terbukti 70\% sampel menyatakan bahwa pesantren mereka menggunakan model keturunan untuk regenerasi kepemimpinan. Sisanya 26\% sudah menggunakan jalur organisasi, dan $4 \%$ caretaker.

Sepintas regenerasi di pesantren persis seperti regenerasi di kerajaan. Seorang raja memiliki putra mahkota yang kemudian diangkat menjadi raja setelah yang bersangkutan meninggal dunia. Pendapat Zamakshari Dhofier yang mengibaratkan pesantren sebagai kerajaan kecil dan kiai adalah rajanya, mungkin ada betulnya. Tapi itu tidak mutlak. Pesantren bukan kerajaan dan kiai tidak pernah menganggap dirinya sebagai raja. Regenerasi di pesantren meskipun melalui jalur keturunan tapi melalui mekanisme kontrol yang ketat. Ada nilai-nilai dasar yang dijadikan syarat untuk menjadi penerus kiai di pesantren. Seorang putra pertama kiai tidak otomatis menjadi pengganti kiai. Dia harus memenuhi nilai dasar yang telah ditetapkan. Jika putra pertama tersebut tidak bisa memenuhi nilai dasar, maka kepemimpinan pesantren akan diberikan kepada orang lain yang lebih layak.

Model regenerasi keturunan memiliki dua varian; pertama penerus adalah anak kandung kiai pendiri dan kedua penerus adalah menantu kiai pendiri. Dari sampel penelitian yang menunjukkan 16 pesantren melakukan regenerasi keturunan, 11 kepada putra dan 5 kepada menantu. KH. Mad Rodja Sukarta pimpinan Pondok Pesantren Darul Muttaqien Parung merupakan menantu dari pendiri pesantren KH. Abdul Manaf Mukhayyar. Demikian pula H. Nurrohim Yunus, M. Phil., pimpinan Pondok Pesantren Darunna'im YAPIA Parung menantu dari Dr. KH. Mukri Aji, MA., pendiri pesantren. KH. Jamhari Abdul Jalal, pimpinan Pondok Pesantren Darunnajah Cipining menantu dari KH. Abdul Manaf Mukhayyar, pendiri pesantren. KH. Ubaidillah, pimpinan Pondok Pesantren Ibnu Aqil adalah menantu KH. Agus Salim, pendiri pesantren. KH. Anwarudin, pimpinan Pondok Pesantren Al-Ikhlas Mega Mendung menantu KH. Syarifudin, pendiri pesantren.

Regenerasi pimpinan pesantren model keturunan yang menjadikan menantu sebagai pengganti pendiri pesantren bukan hal baru. Dari dulu para kiai melakukan tradisi mengawinkan putrinya dengan murid-murid terbaik. Zamakhsyari Dhofier menulis sejarah pesantren Tebuireng Jombang. Kiai Silah pendiri Pesantren Tambakberas Jombang menikahkan putri sulungnya dengan seorang santri bernama Usman. Santri terbaik tersebut kemudian menjadi Kiai Usman dan mendirikan pesantren Gedang di Jombang. Seolah mengikuti tradisi ayah mertuanya, Kiai Usman menikahkan salah satu 
putrinya dengan seorang santri terpandai bernama Asy'ari yang berasal dari Demak (Dhofier, 2011). Kiai Asy'ari merupakan ayah dari pendiri pesantren Tebuireng KH. Hasyim Asy'ari.

Ada 6 pesantren yang model regenerasinya menggunakan System organisasi. Pada model ini penganti kiai ditentukan oleh musyawarah yayasan. Pesantren Darul Fallah Ciampea yang didirikan oleh KH. Soleh Iskandar pada mulanya melakukan regenerasi model keturunan. Berhubung keturunan pendiri sudah sepuh, kepemimpinan pesantren diserahkan kepada yayasan. Berdasarkan hasil musyawarah yayasan, ditetapkan $\mathrm{KH}$. Abdul Hanan Abbas, Lc., sebagai pimpinan.

Pesantren Modern Sahid, Al-Kahfi, Al-Ghazali, Daruttaqwa dan Muallimin Muhammadiyah menerapkan model organisasi dalam regenerasi kepemimpinan. Pimpinan pesantren dipilih secara musyawarah oleh pengurus yayasan. Sosok pilihan merupakan yang terbaik dan dianggap mampu mengemban amanah. Faktor keturunan menjadi tidak dominan dalam pemilihan model yayasan. Siapapun yang kompeten memiliki peluang untuk menjadi pimpinan pesantren.

Pesantren Modern Sahid yang didirikan oleh seorang pengusaha perhotelan telah melakukan dua kali pergantian pimpinan. Kedua pimpinan tersebut tidak memiliki hubungan keturunan dan kekeluargaan dengan pendiri. Pimpinan dipilih dari alumni pesantren modern yang berpengalaman mengelola pesantren dan memiliki visi yang sama dengan pendiri. Hubungan pimpinan pesantren dan pendiri adalah hubungan profesional antara bawahan dan atasan.

Pesantren Terpadu Al-Kahfi didirikan oleh sekelompok akademisi yang peduli terhadap pendidikan agama. Para pendiri termasuk di dalamnya mantan Menteri Sosial masa Presiden Susilo Bambang Yudhoyono, Dr. H. Salim Segaf Al Jufri, ada di dalam kepengurusan yayasan. Pengurus yayasan memilih pimpinan pesantren. Modelnya sama seperti Pesantren Modern Sahid. Demikian juga pesantren Al-Ghazali, bedanya pengurus yayasan terdiri dari keluarga besar pendiri pesantren.

Sedikit berbeda dengan Pesantren Sahid dan Al-Ghazali, Pesantren Muallimin Muhammadiyah tidak berada di bawah naungan yayasan keluarga. Yayasan yang menaunginya adalah yayasan organisasi. Pengurus yayasan adalah beberapa orang tokoh organisasi di daerah tersebut.

Peneliti menemukan sebuah model regenerasi baru terjadi di Pesantren Darul Ulum Lido. Pendiri Pesantren KH. Ahmad Dimyati meninggal dunia dalam usia muda. Saat itu pesantren yang beliau dirikan baru berumur 5 tahun. Kepemimpinan pesantren diserahkan kepada wali amanah yang terdiri dari beberapa orang ustaz senior dan anggota keluarga kiai. Ustaz Ahmad Yani ditunjuk sebagai pimpinan sementara pesantren. 
Model regenerasi caretaker yang terjadi di pesantren kabupaten Bogor hanya satu. Model ini bisa dikatakan kasuistik.

\section{B. Kaderisasi kepemimpinan pondok pesantren di Kabupaten Bogor \\ 1. Nilai dasarkaderisasi}

Para pimpinan pesantren mensyaratkan kadernya memiliki lima kualitas utama; akhlak, keilmuan, ibadah, manajerial dan dedikasi.

a. Akhlak

Akhlak atau sering disebut oleh ahli Barat sebagai karakter menempati peringkat pertama. Para kiai sepakat menjadikan akhlak sebagai prioritas utama nilai dasar kaderisasi. Seorang kader pesantren diarahkan untuk menjadi pimpinan di masa yang akan datang. Sebagai seorang pimpinan lembaga keagamaan tentu akhlak menjadi modal utama.

KH. Ridwan Alawi pimpinan Pondok Pesantren Al-Itqon Cibungbulang saat diwawancara terkait nilai dasar utama yang harus dimiliki seorang kader, dengan tegas menjawab akhlak. Kiai yang juga seorang Qari tersebut menjelaskan bahwa akhlak adalah faktor utama. Keilmuan seberapa banyak pun akan kurang berarti jika tidak dibarengi dengan akhlak mulia. Beliau menyandarkan pendapatnya tersebut dengan hadits Rasul saw. yang artinya, "Sesungguhnya aku diutus untuk menyempurnakan akhlak."

b. Keilmuan

Lebih dari 1/3 sampel memilih keilmuan setelah akhlak sebagai nilai dasar penetapan kader. Fakta ini menunjukkan kesadaran para pemimpin pesantren di kabupaten Bogor akan pentingnya ilmu. Pesantren adalah lembaga ilmu pengetahuan. Seorang pemimpin pesantren menjadi lambang dari keilmuan tersebut. Ilmu dan pesantren tidak bisa dipisahkan.

Keilmuan yang diharapkan dari kader oleh pimpinan pesantren meliputi ilmu agama dan umum. Meski demikian ilmu agama lebih diutamakan daripada ilmu umum. Terutama di pesantren salafiyah, ilmu agama menjadi kunci keberlangsungan pesantren. Kiai di pesantren salafiyah dikenal oleh masyarakat karena keahliannya di bidang ilmu agama. Bahkan di beberapa pesantren, kiai pimpinannya memiliki keahlian di satu bidang ilmu agama. Ada kiai yang ahli di bidang fikih, kiai ahli di bidang ilmu alat yang mencakup Sharaf, Nahwu dan Balaghah, kiai ahli di bidang tafsir, kiai ahli di bidang hadits, kiai ahli di bidang qiroah

Keilmuan bagi seorang calon pemimpin menjadi syarat yang harus dipenuhi. Sejarah pun mencatat peristiwa penetapan Thalut menjadi raja Bani Israil. Kisah tersebut dimuat dengan lengkap dalam Al-Qur'an surat Al-Baqarah ayat 246-251. 
Al-Qur'an menggunakan kata basthotan fil ilmi wal jismi, untuk menunjukkan potensi dalam diri Thalut. Kekuatan ilmu dan fisik yang dimiliki Thalut terbukti membawa kemenangan bagi Bani Israil. Di sini terbukti keilmuan seorang pemimpin sangat berpengaruh terhadap kesuksesan kepemimpinannya.

\section{c. Ibadah}

Di urutan ketiga daftar nilai dasar yang harus dimiliki oleh kader adalah ibadah. Sebanyak 17 orang pimpinan pesantren menyertakan ibadah sebagai nilai dasar kaderisasi yang dilakukan di pesantren yang mereka pimpin. Ini berarti lebih dari setengah sampel. Fakta tersebut menunjukkan bahwa ibadah menjadi elemen yang penting bagi calon pemimpin pesantren.

Kualitas ibadah seorang kiai mencerminkan kedekatannya dengan Sang Pencipta. Semakin baik hubungan kiai dengan Allah, semakin banyak pertolongan yang Allah berikan kepadanya. Islam memperkenalkan istilah mukjizat, karomah dan maunah. Mukjizat adalah perkara di luar kebiasaan yang muncul dari diri seorang Nabi atau Rasul sebagai bukti kenabian atau kerasulan. Karomah adalah perkara di luar kebiasaan yang muncul dari diri seorang wali yang tidak ada kaitannya dengan seruan kenabian atau kerasulan. Sedangkan maunah adalah pertolongan Allah kepada orang beriman yang dikehendakinya.

Kekuatan kepemimpinan kiai baik di lingkungan pesantren pun di masyarakat salah satunya timbul karena karisma. Oleh karena itu masyarakat mengenal istilah kiai karismatik. Martin Van Bruinessen pernah melakukan percakapan pribadi dengan $\mathrm{KH}$. Abdurrahman Wahid terkait dengan karisma yang dimiliki oleh para kiai. Berdasarkan keterangan cucu pendiri Nahdhatul Ulama tersebut, Martin menulis bahwa karisma kiai muncul dari kekuatan spiritual dan kemampuan memberi berkah (Bruinessen \& Martin, 1999).

\section{d. Manajerial}

Dua orang pimpinan pesantren menambahkan kemampuan manajerial sebagai nilai dasar kaderisasi. Meski sangat sedikit dibandingkan dengan tiga nilai pertama yang sudah dibahas, fakta ini cukup menarik. Dilihat dari kacamata kiri, jumlah ini mencerminkan bahwa mayoritas pimpinan pesantren belum menyadari pentingnya manajemen. Dilihat dari kacamata kanan, keberadaan manajerial sebagai nilai dasar kaderisasi meniupkan sebuah harapan. Kiai pimpinan pesantren mulai melirik manajemen sebagai salah satu faktor penunjang pendidikan di pesantren.

Manajemen pun menjadi nilai dasar yang sangat penting bagi regenerasi di pesantren. Seorang calon kiai mesti mengenal manajemen. Dia harus memiliki kecenderungan senang terhadap keteraturan. Manajemen biasanya berbuah disiplin. Dan disiplin identik 
dengan prestasi. Menurut Naceur Jabnoun dalam buku Islam and Management, manajemen yang baik adalah kunci dari keberhasilan sebuah organisasi (Jabnoun, 2012).

e. Dedikasi

Ada satu orang pimpinan pesantren yang menambahkan dedikasi sebagai nilai dasar kaderisasi di pesantrennya. KH. Ahmad Tajuddin, pimpinan Pesantren Daruttaqwa memunculkan dedikasi karena dianggap salah satu elemen keberhasilan seorang pemimpin. Meskipun hanya satu kiai yang menyebutkan dedikasi, ini sangat penting untuk dibahas. Munculnya dedikasi sebagai salah satu nilai kaderisasi di pesantren menjadi harta karun.

Dedikasi timbul dari rasa cinta terhadap profesi. Setiap orang yang berdedikasi pasti menganggap profesinya sebagai yang terbaik. Dia rela mencurahkan segala perhatian untuk setiap kegiatan yang terkait dengan profesinya. Baginya bekerja bukan sebagai beban, tapi sudah menjadi kebutuhan. Dengan melakukan pekerjaan tersebut dia merasa hidup. Sebuah perasaan yang tidak mungkin dimiliki oleh orang yang tidak mencintai profesinya.

Cintanya kepada profesi yang sedang dijalani muncul dari sebuah kesadaran. Dia sadar bahwa apa yang dilakukannya sangat penting. Dia sadar bahwa pekerjaannya memiliki nilai yang tinggi. Kesadaran itu ada dari hasil pemahamannya terhadap tujuan utama dari profesinya.

\section{Model kaderisasi pondok pesantren}

a. Program Kaderisasi

Program kaderisasi di pesantren berlangsung dalam rentang waktu yang panjang. Putra-putri kiai dipersiapkan menjadi pemimpin semenjak mereka masih kecil. Hal ini dilakukan karena para kiai sudah menentukan sejak awal bahwa kepemimpinan pesantren di masa depan akan dipegang oleh salah satu putra atau putrinya. Program yang dilakukan semenjak kecil adalah pendidikan.

Pendidikan bagi kader pesantren dimulai dengan pengajaran al-Qur'an. Bagi kiai pimpinan pesantren kemampuan membaca Al-Qur'an harus dimiliki putra-putrinya semenjak kecil. Saat anaknya sudah mulai bisa bicara, mereka sudah diajari bacaan AlQur'an. Pada mulanya anak-anak kiai yang baru bisa bicara tersebut diajari surat AlFatihah. Model pengajarannya hafalan. Ibu atau bapak membacakan ayat per ayat kemudian diikuti oleh si anak. Surat berikutnya adalah An-Nas, Al-Falaq dan Al-Ikhlas.

Guru yang mengajar mengaji Al-Qur'an bagi putra-putri kiai beragam. Sebagian diajari mengaji oleh orang tua mereka, baik ibu pun bapak, sebagian diajar oleh guru mengaji. Ada juga yang dobel, diajar oleh orang tua dan guru mengaji. Sebanyak 11 orang kiai menyatakan bahwa anak-anaknya diajar mengaji Al-Qur'an oleh orang tua. Dengan jumlah yang sama 11 orang kiai menyatakan anak-anaknya diajar mengaji oleh guru 
mengaji. Sisanya 8 orang kiai menyatakan ikut mengajari anak-anaknya mengaji AlQur'an bersama guru mengaji.

Program pendidikan selanjutnya adalah sekolah formal. Semua anak kiai disekolahkan. Bagi kiai tidak ada fanatisme madrasah di jenjang dasar. Mereka menyekolahkan anak baik di sekolah dasar umum pun madrasah. Setelah anak-anak tersebut lulus sekolah dasar, mayoritas dimasukkan ke pendidikan pesantren. Sebanyak 28 orang kiai memilih pesantren sebagai lembaga pendidikan pasca sekolah dasar bagi putra-putri mereka. Satu orang kiai belum memasukkan putranya ke pesantren karena masih berada di sekolah dasar. Satu orang lagi tidak memasukkan putranya ke pesantren karena alasan memberi cakrawala yang berbeda kepada putranya.

Pimpinan pesantren modern dan salafiyah memiliki kesamaan pendapat terkait dengan pentingnya kader mondok di pesantren. Namun mereka berbeda pendapat tentang harus tidaknya kader meneruskan pendidikan ke jenjang lebih tinggi. Kiai di pesantren modern dan semi modern menyekolahkan putra dan putrinya ke perguruan tinggi. Kiai di pesantren salafiyah tidak menyekolahkan putra dan putrinya ke perguruan tinggi.

Bagi kiai di pesantren modern, pendidikan tinggi sangat penting. Sebagaimana tercermin dalam nilai dasar kaderisasi yang mereka tentukan. Kader harus memiliki gelar sarjana. Sedangkan bagi kiai di pesantren salafiyah, pendidikan tinggi kurang penting. Kader yang mereka harapkan adalah yang menguasai ilmu agama, mahir kitab kuning dan pintar baca Al-Qur'an.

Setelah proses pendidikan, program kaderisasi berikutnya adalah penugasan. Kader yang telah menamatkan sekolah tinggi, kembali ke lingkungan pesantren. Ilmu yang mereka terima selama proses pendidikan harus diaplikasikan. Kiai sebagai penanggung jawab program telah menyiapkan pos-pos tertentu bagi kader yang sudah kembali ke pesantren.

Ada tiga pos tugas yang disiapkan bagi kader. Pertama adalah mengajar formal di kelas, kedua mengemban amanah sebagai pengurus pesantren dan ketiga masuk ke dalam kepengurusan yayasan. Sebanyak 38 \% kader ditugaskan untuk mengajar, $48 \%$ masuk ke dalam struktural pesantren, $2 \%$ menjadi pengurus yayasan, $4 \%$ belum dan 1 $\%$ tidak.

b. Evaluasi Program Kaderisasi

Bagian terakhir dari rangkaian kaderisasi di pesantren adalah evaluasi program kaderisasi. Ada dua jenis evaluasi yang dilakukan oleh pimpinan pesantren; pendekatan personal dan pendekatan manajerial. Evaluasi jenis pendekatan personal mencakup; nasehat, apresiasi dan teguran. Evaluasi jenis pendekatan manajerial meliputi; rapat khusus dan laporan berkala. 
Pimpinan pesantren sampel sebanyak 30 orang kiai menyatakan telah melakukan evaluasi pendekatan personal. Baik kiai pimpinan pesantren modern maupun salafiyah sepakat bahwa nasehat sangat penting untuk mengingatkan kader akan tanggung jawab yang sedang diemban. Tidak ada waktu khusus untuk menasihati. Nasehat disampaikan dalam berbagai kesempatan.

Para kiai menyadari bahwa nasehat merupakan kunci kesuksesan bagi orang yang beriman.

"Demi masa. Sesungguhnya manusia itu benar-benar dalam kerugian. Kecuali orang-orang yang beriman dan mengerjakan amal saleh dan nasehat menasihati supaya menaati kebenaran dan nasehat menasihati supaya menetapi kesabaran."

(Qs Al-Asr: 1-3)

Sama seperti nasehat, apresiasi juga dilakukan oleh seluruh kiai pimpinan pesantren. Mereka sepakat bahwa memberi sanjungan saat kader melaksanakan tugas dengan baik sangat bermanfaat untuk menjaga semangat kerja. Apresiasi yang diberikan kiai kepada kader membuat kader merasa dihargai. Penghargaan tersebut menambah erat hubungan kiai dan kadernya.

Teguran juga dilakukan saat kader melakukan kesalahan. Mayoritas kiai pimpinan pesantren melakukan teguran secara personal. Hal ini dilakukan untuk menjaga wibawa kader. Agar kader mengetahui kesalahannya dan dapat segera memperbaiki sedangkan orang lain tidak banyak mengetahui. Ada juga kiai yang tidak segan menegur kader di muka umum. Sebanyak 5 orang kiai dari 30 sampel melakukan teguran secara terbuka.

Teguran merupakan peringatan agar yang ditegur mengetahui kesalahannya dan berusaha untuk memperbaiki. Islam menyatakan bahwa teguran yang disampaikan dengan cara yang baik dan benar sangat bermanfaat, "Dan tetaplah memberi peringatan, karena sesungguhnya peringatan itu bermanfaat bagi orang-orang yang beriman." (QS Adz-Dzariyah: 55).

Evaluasi dengan pendekatan manajerial tidak dilakukan oleh semua kiai pimpinan pesantren. Kiai pimpinan pesantren salafiyah tidak melaksanakan evaluasi dengan pendekatan profesional. Hal ini dapat dimaklumi karena kiai dan kadernya tidak banyak mengetahui ilmu manajemen. Dan pesantren yang mereka kelola pun belum menerapkan prinsip-prinsip manajemen.

Sebanyak 25 orang kiai melaksanakan rapat khusus dengan kader. Mereka menjadwalkan rapat secara berkala dari yang satu bulan sekali sampai yang satu minggu sekali. Rapat berkala dilakukan untuk memonitor keberlangsungan tugas yang sedang diemban oleh kader. Dalam rapat tersebut kiai memberi pengarahan kepada kader agar melakukan tugas secara baik dan benar. 
Adapun laporan berkala hanya diminta oleh 7 orang kiai. Kebanyakan kiai sudah merasa puas dengan melaksanakan rapat khusus. Bagi mereka laporan berkala tidak diperlukan karena dalam rapat sudah mengetahui progres kerja kader. Sedangkan kiai yang meminta laporan berkala menyatakan bahwa laporan lisan saja tidak cukup. Kader harus belajar membuat laporan tertulis.

Tertib administrasi menjadi target dari kiai yang mewajibkan laporan berkala. Pesantren membutuhkan data tertulis sebagai arsip. Mereka memiliki ruang arsip khusus untuk penyimpanan. Arsip-arsip yang tersimpan rapi sangat berguna bagi keberlangsungan pesantren. Di masa depan saat kader menghadapi suatu persoalan atau akan melaksanakan suatu kegiatan, arsip tersebut bisa menjadi rujukan.

\section{Kesimpulan}

Terdapat tiga model regenerasi di pesantren; keturunan, organisasi dan caretaker. Mayoritas pesantren melaksanakan regenerasi dan kaderisasi model keturunan. Regenerasi di pesantren meskipun melalui jalur keturunan tapi melalui mekanisme kontrol yang ketat. Ada nilai-nilai dasar yang dijadikan syarat untuk menjadi pengganti kiai di pesantren.

Nilai dasar regenerasi dan kaderisasi yang ditetapkan oleh pimpinan pesantren mencakup; akhlak, ibadah, keilmuan, manajerial dan dedikasi. Dua nilai terakhir hanya disebut masing-masing dua dan satu orang pimpinan pesantren. Kebanyakan pimpinan pesantren menaruh perhatian besar terhadap aspek akhlak, ibadah dan keilmuan. Fakta ini menjadi legitimasi pendapat yang menyatakan pesantren sebagai penjaga nilai-nilai agama Islam (Siregar, 2013).

Program kaderisasi yang dilakukan meliputi; pendidikan dan penugasan. Mayoritas pimpinan pesantren menanamkan pendidikan Al-Qur'an kepada kader sejak dini. Kader pun dituntut untuk menguasai kitab kuning sebagai sumber ilmu agama yang terpercaya. Dan sudah mulai banyak kader pesantren yang disekolahkan ke jenjang pendidikan tinggi baik di universitas dalam negeri maupun di luar negeri.

Penugasan diberikan kepada kader yang sudah menamatkan pendidikan di jenjang tinggi. Kader diberi kesempatan untuk mengajar di kelas. Selian itu beberapa kader sudah dilibatkan dalam kepengurusan pesantren dan yayasan.

Evaluasi kaderisasi terus dilakukan oleh pimpinan pesantren. Mereka melakukan pendekatan personal dan manajerial. Pimpinan pesantren modern melakukan dua jenis pendekatan tersebut, sedangkan pimpinan pesantren salafiyah hanya menggunakan jenis pertama.

\section{Daftar Pustaka}


Al-Madyuni, M. Q. (2013). Sang Kiyai Tiga Generasi. Jombang: Pustaka Al-Khumul.

Bruinessen, V., \& Martin. (1999). Kitab Kuning Pesantren dan Tarekat. Mizan: Bandung. Burhan, B. (2010). Metode penelitian kuantitatif: komunikasi, ekonomi, dan kebijakan publik serta ilmu-ilmu sosial lainnya. Jakarta: PT. Prenada Media Group.

Dhofier, Z. (2011). Tradisi pesantren: studi pandangan hidup kyai dan visinya mengenai masa depan Indonesia. Jakarta LP3ES.

Jabnoun, N. (2012). Islam and management: Your ultimate guide to running a business from an Islamic perspective. International Islamic Publishing House (IIPH).

Masqon, D. (2015). Buku Profil Pondok Modern Gontor. Ponorogo: Gontor Press.

Mastuhu. (1994). Dinamika Sistem Pendidikan Pesantren. Jakarta: INIS.

Pribadi, Y. (2013). Religious Networks in Madura; Pesantren, Nahdlatul Ulama and Kiyai as the Core of Santri Culture. Jurnal Al-Jami'ah, 51 (1)

Siregar, F. M. (2013). Religious leader and charismatic leadership in Indonesia: the role of Kyai in Pesantren in Java. Jurnal Kawistara, 3(2).

Sugiyono, P. (2013). Metode Penelitian Kuantitatif, Kualitatif, Dan R\&D. Bandung:, Alfabeta.

Wahid, M. (2008). The Metamorphosis of Pesantren, International Journal of Pesantren Studies, 2 (2).

Zaini, A., \& K.H. (2011). Abdul Wahid Hasyim Pembaru Pendidikan Islam dan Pejuang Kemerdekaan. Jombang: Pesantren Tebuireng.

Zarkasyi, A. S. (2005). Gontor dan Pembaharuan Pendidikan Pesantren. Jakarta: Rajagrafindo Persada. 